\title{
AS CONCEPÇÕES DE PODER E AUTORIDADE NECESSÁRIAS À INTERPRETAÇÃO DA LEI No . 13.869/2019
}

\section{THE CONCEPTIONS OF POWER AND AUTHORITY NECESSARY FOR THE INTERPRETATION OF LAW No $\mathbf{N}^{\circ}$ 13.869/2019}

\author{
Willibald Quintanilha Bibas Netto ${ }^{1}$ \\ Rafael Fecury Nogueira ${ }^{2}$
}

\section{RESUMO}

O advento da Lei $n^{\circ}$ 13.869/2019 causou muita polêmica ao criminalizar condutas oriundas de abuso de autoridade. Ocorre que grande parte desta polêmica reside no fato de a lei utilizar de elementos do tipo de natureza sui generis. Assim, no intuito de compreender melhor as disposições gerais da referida lei, o presente trabalho pretende analisar algumas concepções filosóficas de Poder e Autoridade, para depois compreender como tais concepções auxiliam na interpretação jurídica dos elementos subjetivos (psíquicos) constantes na Lei $\mathrm{n}^{\circ}$. $13.869 / 2019$.

Palavras-Chave: Poder. Abuso de Autoridade. Direito Penal. Processo Penal. Constituição

\begin{abstract}
The advent of Law $n^{\circ} .13 .869 / 2019$ brought on a lot of controversy by criminalizing specific behaviors arising from abuse of authority. Therefore, much of this controversy resides in the fact that the law uses elements of a sui generis nature. Hence, in order to better understand the general perception of this law, the present study intends to analyze the main philosophical
\end{abstract}

\footnotetext{
${ }^{1}$ Mestrando em Direitos Fundamentais pela Universidade da Amazônia (UNAMA). MBA em Direito: Civil e Processual Civil pela Fundação Getúlio Vargas (FGV). Graduado em Direito pelo Centro Universitário do Estado do Pará (CESUPA). Advogado Criminalista Sócio do Escritório Bibas, Gaia, Mendonça e Moura Advocacia e Consultoria Jurídica. Tem experiência na área de Direito Penal, Processual Penal, Direito Civil e Processual Civil. E-mail: willibaldnetto@ gmail.com. Orcid: http://orcid.org/0000-0002-1816-9942.

${ }^{2}$ Doutor e Mestre em Direito Processual Penal pela Faculdade de Direito da Universidade de São Paulo (USP), Especialista em Direito e Processo Penal pela Universidade Estadual de Londrina (UEL). Professor do Programa de Mestrado em Direitos Fundamentais da Universidade da Amazônia (UNAMA), Professor de Direito Processual Penal do curso de graduação da UNAMA e Professor de Direito Processual Penal do Centro Universitário do Estado do Pará (CESUPA). Autor do Livro A Decisão de Pronúncia no Processo Penal Brasileiro: valoração da prova e limites à motivação, publicado pela editora Lumen Juris, 2018; Autor do Livro; Foro por prerrogativa de função no processo penal: investigação, processo e duplo grau de jurisdição, publicado pela editora Revista dos Tribunais, 2020. Tem experiência na área do Direito, com ênfase em Direito Processual Penal, Direito Penal e Direito Eleitoral. E-mail: rafaelfecury@uol.com.br. Orcid: http://orcid.org/0000-00017055-4066.
} 
conceptions of Power and Authority, to later understand how such assimilations can assist in the legal interpretation of the subjective (psychic) elements contained in Law $n^{\circ}$. 13.869/2019. Keywords: Power. Abuse of Authority. Criminal Law.

\section{INTRODUÇÃO}

A presente pesquisa se volta ao estudo da Lei no . 13.869/2019 (Nova Lei de Abuso de Autoridade) que, além de polêmico ao criminalizar condutas específicas praticadas por agentes políticos em abuso de autoridade, também, teve o condão de introduzir em seu artigo $1^{\mathrm{o}}$, como motivos determinantes do injusto do fato, alguns elementos subjetivos especiais, consistentes em uma finalidade específica - como prejudicar outrem ou beneficiar a si mesmo -, bem como um estado psíquico determinado - de mero capricho ou satisfação pessoal.

Em assim sendo, eis o problema de pesquisa: qual o sentido empregado aos vocábulos 'poder' e 'autoridade' presente nas disposições gerais da Lei $\mathrm{n}^{\circ}$. 13.869/2019? De que forma eles podem contribuir para uma interpretação constitucional deste diploma legal?

O desenvolvimento da pesquisa terá como base a revisão bibliográfica acerca do tema poder e autoridade, visando identificar suas principais concepções e de que forma elas podem auxiliar na hermenêutica constitucional dos elementos subjetivos constantes na Lei $\mathrm{n}^{\circ}$. $13.869 / 2019$.

Objetiva-se, desse modo, fazer um trabalho com o intuito de identificar a relação entre os conceitos de poder e de autoridade e, dessa forma, almeja-se demonstrar como a Lei $\mathrm{n}^{\circ}$. 13.869/2019 utiliza de tais conceitos para reafirmar os ditames constitucionais a partir do controle das relações de poder.

Para alcançar as considerações finais do trabalho, propõe-se trabalhar, num primeiro momento, analisando as principais concepções de poder e autoridade, e como se deu o seu desenvolvimento. Depois, discutir-se-á sua aplicabilidade no caput do artigo $1^{\circ}$ da Lei $\mathrm{n}^{\circ}$. 13.869/2019, bem como no seu parágrafo único. Após compreendermos toda a profundidade e alcance das disposições gerais da nova lei de abuso de autoridade, demonstrar-se-á como ela se consubstanciam em verdadeira garantia de todo cidadão frente ao poder do Estado, assim como o Direito Penal e Processual Penal.

No artigo utilizar-se-á o método hipotético-dedutivo no que diz respeito à análise das concepções de poder e autoridade e suas relações com o caput e $\S 1^{\circ}$ do art. $1^{\circ}$ da Lei $n^{\circ}$. 13.869/2019, será utilizado, como metodologia de análise, a pesquisa dogmático-jurídica de natureza bibliográfica, por meio da consulta de obras, legislação e jurisprudência brasileira 
atinente à temática. A pesquisa tem como objetivo fundamental a introdução ao debate sobre as concepções jurídicas de 'poder' e 'autoridade' no intuito de contribuir para a interpretação constitucional da Lei $n^{\circ}$. 13.869/2019, sem intenção de esgotar o assunto, que merece atenção crescente da academia.

\section{AS CONCEPÇÕES DE PODER E AUTORIDADE}

Quando falamos de autoridade, evocamos toda a carga simbólica que o termo congrega. Portanto, é de fundamental importância analisarmos não apenas o seu significado na língua portuguesa, mas principalmente como seu contorno foi sendo traçado a partir de diversas concepções filosóficas e políticas, as quais têm o condão de influenciar a racionalidade da interpretação jurídica sobre as normas que dispõe sobre poder e autoridade. Então, neste tópico analisaremos como diversos filósofos desenvolveram suas concepções a respeito de poder e autoridade.

Inicialmente, vejamos o significado que o vocábulo traduz:

Autoridade: (do latim auctoritate) 1. Direito ou poder de se fazer obedecer; de dar ordens, de tomar decisões, de agir etc. 2. Aquele que tem tal direito ou poder. 3. Os órgãos do poder público. 4. Aquele que tem por encargo fazer respeitar as leis; representante do poder público 5. Poder atribuído a alguém, domínio: autoridade paterna. 6. Influência, prestígio, crédito. 7. Indivíduo de competência indiscutível em determinado assunto: "F. é uma autoridade em física nuclear”. 8. Permissão, autorização. (FERREIRA, 1999, p. 236).

Assim sendo, o significado da palavra 'autoridade' pode ser empregado para se referir àquele que, em virtude de uma determinada condição, se faz obedecer ou respeitar. Interessante notar, ainda, a intima conexão da palavra 'autoridade' com o poder exercido por alguém, inclusive em relações de domínio sobre outrem.

A análise do contexto histórico da ideia de autoridade nos remete à Platão que, ao tentar compreender a autoridade como um processo legítimo, passou a observar diversos tipos de relações: do pastor e seus carneiros, do médico com os doentes etc. Em sua análise, Platão constatou que através do conhecimento se estabeleceu um vínculo de confiança entres as partes das relações observadas (PLATÃO, 2006). Segundo o referido filósofo, em situações onde uma parte detém o conhecimento e a outra não, o fato de um dominar o conhecimento sobre determinado assunto posicionaria a outra parte em situação hierárquica imediatamente inferior. Para Platão, o governante seria a autoridade na relação com o particular porque teria o domínio sobre as questões humanas.

Aristóteles também analisou o conceito de autoridade, inicialmente, como algo intrínseco às relações familiares. A autoridade se apresentaria como algo natural, uma 
característica inata, assim como a própria condição daquele que obedece, ou seja, ambos nasceriam com esse atributo. Portanto, analisando a autoridade a partir do ponto de vista privado, haveria uma relação hierárquica entre pais e filhos, maridos e esposas etc.

Destarte, para o referido filósofo a autoridade seria configurada como algo natural, onde algumas pessoas nascem destinadas a mandar e outras à obedecer. Nesse sentido, Aristóteles dissertava que:

Há, por ação da natureza e para a manutenção das espécies, um ser que manda e outro que obedece. Pois aquele que tem inteligência capaz de prever tem, de modo natural, autoridade e poder de chefe; aquele que não tem senão a força física para executar deve, obrigatoriamente, obedecer e servir. (ARISÓTELES, 2004, p. 12).

A autoridade, então, era ligada à figura do homem na família, o qual era visto como um governante que geria a economia familiar e organizava administrativamente seu lar, sustentando ainda uma inteligência e entendimentos superiores. Por esta razão Aristóteles afirmava que:

Existe a autoridade do senhor: parte desta autoridade referente às coisas necessárias à existência não requer que o que manda saiba consegui-las por si, mas saiba, sobretudo, fazer uso delas. O restante é servil. (...) Não é necessário, portanto, que o homem de bem, homem de Estado ou o bom cidadão aprenda tais espécies de labor (atividades domésticas) que apenas são convenientes àqueles destinados a obedecer. (ARISTÓTELES, 2004, p.84).

Então, considerando que o homem era visto como naturalmente superior, a hierarquia, na visão Aristotélica, era uma forma de organizar o espaço privado, a partir da promoção de um bem-estar que favorecia a todos, pois comandados por quem tinha verdadeira capacidade para tanto.

Aristóteles, também analisou o aspecto da autoridade no espaço público, local onde o cidadão deve ter participação nos assuntos do governo e, por meio de uma autoridade estabelecida, poderia deliberar sobre os assuntos da cidade. É interessante notar que, diferente do âmbito privado, para o referido autor, um bom cidadão deveria saber mandar, mas também obedecer, uma vez que parte-se do princípio da igualdade entre eles (homens):

$\mathrm{Na}$ ordem política, tal como ela existe na maior parte dos povos, obedece-se e comanda-se alternadamente. Todos os homens livres são considerados iguais por natureza e todas as diferenças se eclipsam;(...). (ARISTÓTELES, 2004, p. 27).

No espaço público, a hierarquia entre os cidadãos não era absoluta e nem essencial, mas eventual, e, por isso, um bom cidadão deve saber mandar e obedecer, pois em alguns momentos estará como governante e em outros como governado. Ou seja, a autoridade 
política, exercida entre homens livres demonstra a necessidade de haver a alternância de poder, sendo o "mandar" e o "obedecer" dependentes entre si, e, portanto, haveria uma paridade entre os cidadãos livres (homens), que poderiam, alternativamente, ocupar um lugar superior para tomar decisões nos assuntos de interesse da sociedade a partir do revezamento dos momentos de obediência e comando.

É possível perceber, então, que no pensamento desenvolvido por Aristóteles, a autoridade pertence aos melhores, os quais são definidos pela natureza:

Quanto ao sexo, a diferença é indelével: qualquer que seja a idade da mulher, o homem deve conservar sua superioridade. A autoridade dos pais sobre os filhos é uma espécie de realeza; todos os títulos ali se encontram: o da geração, o da autoridade afetuosa e o da idade. (ARISTÓTELES, 2004, p. 27).

Podemos dizer que, antigamente, o teorema fundamental da concepção de autoridade era a divisão da sociedade em duas classes, uma que possui por natureza o direito de exercer a autoridade e outra que sempre estará em uma posição de obediência. Como muito bem observam Maria Carmen Euller Torres e Lucia Rabello de Castro:

A tradição romana, juntamente com o pensamento grego, ganhou
continuidade com a religião católica. Santo Agostinho é considerado o
filósofo que revisitou os ensinamentos de Platão e vinculou a filosofia grega
aos dogmas cristãos. Podemos dizer que Agostinho foi o amálgama
filosófico entre a Antiguidade e a religião católica da Idade Média.
(TORRES; CASTRO, 2014, p. 93).

Nesse sentido, a autoridade ainda era uma característica "natural", mas seu fundamento era divino, pois era Deus que transferia sua autoridade a determinados homens, concedendo aos pais o poder biológico de educar seus filhos, ao Papa, o poder de guiar a religião, e à igreja, o direito de ditar as leis da sociedade repartindo o poder com as autoridades eclesiásticas, os príncipes e os governantes. Sendo assim, a autoridade se baseava na divindade, a ponto de considerar o soberano como representante de Deus na Terra. Vejamos a doutrina exposta no capítulo XIII da Epístola aos romanos de São Paulo:

Toda alma esteja sujeita às potestades superiores, porque não há potestade que não venha de Deus; e as potestades que há foram ordenadas por Deus. Por isso, quem resiste à potestade resiste à ordenação de Deus; e os que resistem trarão sobre si mesmos a condenação. Porque os magistrados não são terror para as boas obras, mas para as más. Queres tu, pois, não temer a potestade? Faze o bem, e terás o seu louvor. Porque ela é ministra de Deus para teu bem. Mas, se fizeres o mal, teme, porque ele não traz em vão a espada. Pois é ministra de Deus, vingadora para o castigo daquele que pratica o mal. Por isso, é necessário que lhe estejais sujeitos, não somente por causa do castigo, mas também por obrigação de consciência. (BÍBLIA, 2015, p. 1738) 
Na lógica medieval, a autoridade sempre esteve vinculada ao poder dos Reis e da Igreja Católica, ou seja, estava relacionada a quem tinha poder para se impor, os quais gozavam de autoridade valida porque todo poder vinha de Deus.

É interessante notar que a concepção de autoridade, tanto na Antiguidade, quanto na Idade Média, era completamente independente do consenso de quem obedecia, pois fundamentada em uma condição advinda da natureza, sendo que, no medievo, o temor a Deus e o medo gerado pelos possíveis castigos contribuíram, ainda mais, para que a autoridade da igreja, juntamente com o poder dos reis, se mantivesse intocável pelos séculos que precederam à era moderna.

Percebe-se, então, que a igreja, herdando parte dos dogmas da antiguidade, contribuiu para o desenvolvimento de um pensamento de autoridade pautado na tradição, pois ao perpetuar o mito de uma origem do universo garantiu a durabilidade de seus dogmas por muitos séculos. Hannah Arendt explica que:

Na medida em que a Igreja Católica incorporou a filosofia grega à estrutura de suas doutrinas e crenças dogmáticas, ela amalgamou o conceito político romano de autoridade, que era inevitavelmente baseado em um início, à noção grega de medidas e regras transcendentes. (ARENDT, 1979, p. 170).

Assim, a autoridade da igreja estava pautada em um poder político, junto à realeza medieval e em um poder transcendente ligado aos poderes sobrenaturais de Deus.

Ocorre que, na modernidade, a partir do momento em que a verdade passou a não mais ser buscada por meio da contemplação e a ciência passou a tomar a frente das explicações sobre as coisas da vida, o ser humano se tornou mais ativo em seu processo de vida, passando a se ver como protagonista da construção de sua própria realidade e, como consequência disso, a referida noção de origem de todas as coisas passou a ser questionada, se afastando do sobrenatural.

Nesse diapasão, Max Weber fala de dominação e autoridade, utilizando tais vocábulos como sinônimos. O referido doutrinador chama de 'dominação' a probabilidade de encontrar obediência para ordens específicas dentro de determinado grupo de pessoas. Segundo ele:

Em cada caso individual a dominação ("autoridade") assim definida pode basear-se nos mais diversos motivos de submissão: desde o hábito inconsciente até considerações puramente racionais, referentes a fins. Certo mínimo de vontade de obedecer, isto é, de interesse (externo ou interno) na obediência, faz parte de toda relação autêntica de dominação. (WEBER, 2000, p. 139).

Sendo assim, Max Weber entende que há três tipos puros de dominação legítima, cuja vigência pode ser de caráter legal (ou racional), tradicional e carismático. A dominação de 
caráter legal é aquela que se origina através de regras formalmente estabelecidas, que vinculam a todos a partir da criação de direitos e obrigações, a 'burocracia' é citada como seu exemplo mais puro, onde é possível perceber uma racionalidade baseada em normas que são criadas e modificadas através de um estatuto sancionado. A dominação de caráter tradicional, por seu turno, seria aquela suportada em virtude da fidelidade à tradição presente em determinado meio social, ou seja, presta-se obediência à determinada pessoa em virtude de ela possuir uma dignidade que se julga sagrada. O patriarcalismo é o tipo mais puro desta dominação, onde o governante é o patriarca ou senhor, os dominados são os súditos e o funcionário é o servidor. Por fim, a dominação de caráter carismático seria a decorrente de uma característica do indivíduo, manifestada em qualidades superiores aos outros membros do grupo (capacidades heroicas e exemplares ou poder do espírito e do discurso) que fazem com que os outros o elejam como líder e o obedeçam em virtude de suas qualidades pessoais. Os tipos mais puros são a autoridade do profeta, do herói guerreiro e do grande demagogo (WEBER, 2000, p. 141).

Weber alerta, ainda, que sua doutrina não pretende "encaixar" toda realidade histórica acerca do domínio em um dos referidos caráteres de dominação. Em verdade, ele afirma que: "o fato de que nenhum dos três tipos ideais (...) costuma existir historicamente em uma forma realmente "pura", não deve impedir em ocasião alguma a fixação do conceito na forma mais pura possível." (WEBER, 2000, p. 141).

Nesse sentido, ao tratar da distribuição de poder dentro da comunidade, Max Weber (1999, p. 175) define, genericamente, poder como: “(...) a probabilidade de uma pessoa ou várias impor, numa ação social, a vontade própria, mesmo contra a oposição de outros participantes desta.".

Por sua vez, Hannah Arendt propõe retornar ao pensamento político greco-romano, fundamentando o conceito de poder no consentimento. Ou seja, a partir da ideia de origem / começo, mas sem o aspecto religioso da idade média, é possível chegarmos ao conceito de fundação, um momento de início, o qual é analisado por Arent, a partir da reflexão de autoridade sob uma perspectiva política e não mais ligada às relações "naturais" ou religiosas de hierarquia.

Tomando como base o pensamento greco-romano, a referida doutrinadora identifica que as relações hierárquicas de autoridade só poderiam invocar legitimidade se estivessem baseadas em um suposto começo, como por exemplo, na relação entre pais e filhos, sendo os 
primeiros os porta vozes de uma história inicial, de uma gênese que os últimos não teriam acesso sem eles.

Maria Carmen Euller Torres e Lucia Rabello de Castro explicam o pensamento de Arendt, ao analisar a origem da palavra autoridade, sob a ótica greco-romana:

Pela definição da palavra autoridade, vimos que vem do latim auctoritate que quer dizer direito ou poder de fazer-se obedecer, tomar decisões, agir, fazer respeitar as leis. Também pode ser analisada como derivada de augere, que significa aumentar. Sendo assim, quem teria autoridade seriam aquelas pessoas responsáveis por fazer aumentar ou perpetuar aquilo que os antigos haviam criado. Dito de outra forma, autoridade seria aumentar os domínios da tradição, o sujeito tenderia a crescer como autor, como construtor de algo novo, porém voltado ao passado já herdado. (TORRES et al., 2014, p. 93).

Nesse sentido, os romanos pautaram a ideia de autoridade na noção de fundação fundar algo novo que ficaria como herança para as gerações futuras. Portanto, a autoridade estava nas mãos dos anciões que haviam participado do momento histórico de fundação da cidade, os quais tem o dever de transmitir todos os valores primordiais deste momento fundacional para as gerações futuras.

Arendt, então, ao observar esse aspecto coletivo das relações de poder e autoridade no governo romano, bem como no ateniense, sustenta que o poder tinha como fonte o próprio povo, se consubstanciando na "habilidade humana não apenas de agir, mas de agir em conjunto, em comunidade" (ARENDT, 1999, p. 44). Ou seja, em Arendt, o poder é uma ação em concerto que funda determinada comunidade. Desse modo, em busca da manifestação mais originária do fenômeno político, a referida autora, valendo-se da experiência política romana, identificou que o momento fundacional de determinada comunidade é oriundo de uma ação em conjunto, sendo esta a gênese de uma "esfera pública" de onde o poder retira sua legitimidade. Nas palavras de Arendt: "o poder emerge onde quer que as pessoas se unam e ajam em concerto, mas sua legitimidade deriva mais do estar junto inicial do que de qualquer ação que então possa seguir-se” (ARENDT, 2001 apud PERISSINOTTO, 2004, p. 120)

Ocorre que, segundo ela, esse momento de poder é um "momento fugaz", que por si só não garante a durabilidade da comunidade política, daí sua necessária relação com o conceito de autoridade, uma vez que esta é oriunda do "apoio do povo", o qual nada mais é do que a continuação do ato fundacional (ARENDT, 2007, p. 212). Ou seja, o poder enquanto fundação define as regras e valores de uma comunidade, sendo a autoridade exercida e obedecida por todos, em virtude do reconhecimento do momento fundacional. Então, relacionando tradição e autoridade, Hannah Arendt disserta: 
Nesse contexto basicamente político é que o passado era santificado através da tradição. A tradição preservava o passado legando de uma geração a outra o testemunho dos antepassados que inicialmente presenciaram e criaram a sagrada fundação e, depois, a engrandeceram por sua autoridade no transcurso dos séculos. Enquanto essa tradição fosse ininterrupta, a autoridade estaria intacta; e agir sem autoridade e tradição, sem padrões e modelos aceitos e consagrados pelo tempo, sem o préstimo da sabedoria dos pais fundadores, era inconcebível. A noção de uma tradição espiritual e de autoridade de matéria de pensamento e de ideias deriva aqui do âmbito político sendo portanto essencialmente derivativa (...) (ARENDT, 1979, p. 166).

Nesse sentido, é muito interessante o raciocínio desenvolvido por Renato M. Perissinotto, que, citando Arendt e Ricouer, conclui: “por conseguinte, a autoridade não é poder; este é dinâmico, instável, fugaz; aquela é tradicional e estável (Arendt 2002: 164-66; Ricoeur 1989: 155-56). Podemos dizer, então, que a autoridade é a institucionalização do poder.” (PERISSINOTTO, 2004, p. 121).

Na década de 1970, Michel Foucault, voltando seus estudos à esfera do poder e buscando compreendê-lo, desenvolveu a teoria da Microfísica do Poder, por meio da qual passou a afirmar que o Poder não é um bem que se possui, se acumula ou se troca. Em verdade, o 'poder' permearia tudo, estando em todos os lugares, constituindo uma rede que cobre toda a sociedade (transmissão em rede) (FOUCAULT, 1979, p. 08).

Na visão de Foucault, o 'poder' é visto como um exercício que não está centralizando nas grandes instituições como a Economia, a Política, o Estado ou a Família. O ‘poder' é um feixe de relações que se exerce de maneira assimétrica, e, por isso, ele está em todos os espaços.

Então, o 'poder' não pode ser concebido apenas como repressão, como submissão da vontade dos governados à dos governantes, bem como não pode ser resumido à interdição e proibição da lei, ou seja, o 'poder' não se esgota na fórmula "você não deve", como se aquele que se recorre a ela concentrasse todo 'poder' e o outro que deve acatar não tivesse nenhum.

Destarte, ninguém detém, completamente e o tempo todo, o monopólio do 'poder', sendo visível, portanto, que Foucault rompe com a concepção clássica do 'poder' ao sustentar que ele não está materializado em lugares específicos, em vez disso, o 'poder' está diluído no tecido social, está presente em todos os lugares (é onipresente), pois se apresenta como uma imensa rede que engloba tudo e todos. Ou seja, o 'poder' transcende os indivíduos, pois ele está em uma complexa rede de relações que é composta de saberes e discursos, então, determinado grupo se mantém coeso por causa de seus discursos, sendo guiado por metas e 
objetivos, obedecendo à uma lógica e racionalidade interna oriundas do 'poder', sendo este sempre estratégico, portanto.

Nesse sentido, o 'poder' está nas relações, mas não apenas na relação que chamamos de políticas, pois há Poder, também, nas relações entre pais e filhos, entre cônjuges, amigos, relações de trabalho etc., Assim, as relações de poder não são negociáveis, pois ele está nos micro espaços, portanto, ninguém está fora das relações de 'poder' e sempre haverá alguma situação em que o 'poder' será exercido sobre si ou outrem, logo, não é algo que se conquiste, que se possua ou se perca, mas algo que todos os indivíduos exercem e sofrem, ele só existe se é exercido.

É por isso que Foucault denominou sua teoria de 'Microfísica do Poder', pois a atenção está voltada para as pequenas relações e não para os grandes movimentos políticos, havendo uma multiplicidade de jogos de força e de lutas estabelecidas entre os indivíduos nas mais diversas situações, desde das relações interpessoais até os sistemas administrativos do Estado. Ou seja, as relações de Poder são imanentes, inata à todo e qualquer tipo de relação social, emanando dela como seu efeito imediato.

Por esta razão, Foucault sustenta que o 'poder' tem a sua gênese de baixo, isto é, vem das pequenas situações, são correlações de força microscópicas que sustentam os macro poderes que enxergamos de forma mais imediata. Ou seja, é a partir das pequenas relações de Poder (microfísica) que se constroem os aparelhos de Poder Político estabelecidos nas macro relações sociais, onde estamos acostumados a ver com maior clareza o Poder sendo exercido.

Assim, Foucault identifica o 'poder' como verdadeira fonte de produção social, pois a partir dele se constroem diversos mecanismos por meio dos quais as relações de poder se exercem, interditando certas ações, mas também produzindo outras. É por isso que, ao analisar as sociedades ocidentais, Foucault afirma que podemos perceber "Tecnologias de Poder" distintas, as quais se sucederam como as principais formas de organização política. Vejamos:

O 'Poder da Soberania' foi aquele que embasou os regimes monárquicos, era o direito que o soberano tinha sobre a vida e a morte de seus súditos, pois detinha, por exemplo, o poder de estabelecer leis que se aplicavam a todos, mas não a ele mesmo.

Na modernidade, a autoridade se constituiu como aliada da ciência, que passou a dar as explicações sobre os acontecimentos e ser a grande representante da verdade sob as regras da racionalidade científica. 
Foi assim que as sociedades de soberania começaram a dar lugar à sociedade disciplinar, sendo o 'Poder Disciplinar' aquele centrado nas instituições como a família, o exército, os asilos, as escolas etc. Ou seja, o 'poder' está concentrado em lugares voltados ao disciplinamento, os quais provocam verdadeiro poder de coerção sobre o indivíduo. É um tipo de 'poder' que se exerce sobre seus corpos, onde, por meio da disciplina, o indivíduo pode ser conhecido, controlado e explorado, tirando-se dele tudo que pode oferecer.

Em verdade, se antes as leis incidiam direto sobre o corpo dos criminosos para que todos pudessem ver os seus efeitos, na Modernidade, o controle passou a acontecer de forma mais sutil, efetuado por uma série de outros "poderes paralelos", como as já citadas instituições pedagógicas, médicas, psiquiátricas, dentre outras.

Por fim, Foucault também trabalha com conceito de Biopoder / Biopolítica, a partir do estudo de como o Estado é capaz de administrar a própria vida de uma população, vinculando um poder político à própria vida, onde podemos citar como exemplo, as práticas racistas do regime nazista, bem como os controles de natalidade realizados em alguns países.

Assim, Foucault nos demonstra que as relações de poder vão além daquilo que é físico e visível, sendo imanentes a todo e qualquer tipo de relação social, e, portanto, o Estado não detém seu monopólio, apenas o exerce de maneira macro, mas tal exercício tem sua gênese desde as pequenas relações de poder, as quais formam uma espécie de mecanismo de produção de saberes, discursos e objetos que por se estabelecerem como uma determinada verdade são, portanto, aceitos: “O que faz com que o poder se mantenha e que seja aceito é simplesmente que ele não pesa só como uma força que diz não, mas que de fato permeia, produz coisa, induz ao prazer, forma saberes, produz discursos" (FOUCAULT, 1979, p. 08).

Diante de todo o exposto, ao analisar as diversas acepções acerca do significado de autoridade e poder, é possível percebemos o completo deslocamento de seu simbolismo, que migra de uma concepção naturalista para um pensamento mais técnico, onde o foco é a ciência, que busca racionalidade para as próprias relações humanas. Por essa matriz de pensamento, Foucault relaciona poder e política, na essência da palavra, numa percepção onde o conhecimento ou o conjunto de verdades são capazes de determinar uma relação de poder historicamente sustentada. No momento em que conferimos à ciência status de detentora da verdade, conferimos a ela a autoridade de explicar também os fenômenos humanos.

Sendo assim, em que pesem as referidas acepções de autoridade e poder não terem sua análise voltadas especificamente ao âmbito jurídico, elas são de grande valia para nos ajudar a 
interpretar a nossa legislação pátria, conferindo maior racionalidade ao aferir a responsabilidade de uma autoridade legalmente estabelecida.

Conclui-se, então, que em que pese não ser possível identificar um conceito fechado sobre autoridade e poder, uma vez que suas concepções estão em constante modificação através do tempo. Entretanto, percebemos que as concepções de autoridade sempre estiveram, em maior ou menor grau, ligada a ideia de 'cuidar' e 'administrar', sendo que quanto maior o nível de responsabilidade atribuída à autoridade, para que ela execute este 'cuidar', mais sua concepção se afasta da ideia pura e simples de 'poder'.

\section{PODER E AUTORIDADE NO DIREITO BRASILEIRO}

Diante de tudo de que foi exposto, é importante analisar as concepções de poder e autoridade tratadas por alguns dos referidos autores e transportá-las para o universo do Direito. Então, sob à luz dessas concepções, serão analisados alguns dispositivos legais no intuito de identificar em que sentido a Lei $\mathrm{n}^{\circ}$. 13.869/2019 incorporou as expressões 'poder' e 'autoridade' e qual a relação estabelecida entre elas.

O parágrafo único do artigo primeiro da Constituição Federal de 1988 declara que:

Art. $1^{\circ}$ A República Federativa do Brasil, formada pela união indissolúvel dos Estados e Municípios e do Distrito Federal, constitui-se em Estado Democrático de Direito e tem como fundamentos:

(...)

Parágrafo único. Todo o poder emana do povo, que o exerce por meio de representantes eleitos ou diretamente, nos termos desta Constituição.

Destarte, a concepção constitucional de 'poder' se assemelha à concepção de Hannah Arendt, pois reflete o estar junto inicial, o momento fugaz em que povo declarou todos os seus Direitos Fundamentais, bem como o modo que este 'poder' será exercido. Ou seja, o referido dispositivo legal registra o agir em concerto do povo brasileiro, a criação do Estado, o momento fundacional que confere legitimidade (autoridade) as regras estabelecidas via democracia representativa.

Assim, coube ao Direito Administrativo, ao tratar de princípios e regras que disciplinam a função administrativa e que abrange entes, órgãos, agentes e atividades desempenhadas pela Administração Pública na consecução do interesse público, definir quem são os agentes responsáveis por servir de instrumento de realização das vontades do Estado.

Por este motivo, Celso Antônio Bandeira de Mello (2015, p. 250) ensina que os agentes públicos têm designação amplíssima, eis que envolve todos os sujeitos que genérica e indistintamente servem ao poder público "como instrumentos expressivos de sua vontade ou 
ação, ainda quando o façam apenas ocasional ou episodicamente". Sendo assim, o referido doutrinador enfatiza que todos os agentes públicos:

(...) estão sob um denominador comum que os radicaliza: são, ainda que alguns deles apenas episodicamente, agentes que exprimem manifestação estatal, munidos de uma qualidade que só possuem porque o Estado lhes emprestou sua força jurídica e os habilitou a assim agirem ou, quando menos, tem que reconhecer como estatal o uso que hajam feito de certos poderes. (BANDEIRA DE MELLO, 2015, p. 255, grifo nosso).

Hely Lopes Meirelles (2016, p. 79) afirma que agentes públicos são todas as pessoas incumbidas, definitiva ou transitoriamente, do exercício de alguma função estatal. Os agentes normalmente desempenham função de órgão, distribuídas entre os cargos de que são titulares. Podem, todavia, desempenhar função sem cargo: "Em qualquer hipótese, o cargo ou a função pertencem ao Estado, e não ao agente público".

Nesse diapasão, muito interessante é o conceito de autoridade presente no $\S 1^{\circ}$ do art. $1^{\circ}$ da Lei $n^{\circ} .12 .016 / 2009$ (Lei do Mandado de Segurança). Vejamos:

Art. $1^{\circ}(\ldots)$

$\S 1^{\circ}$ Equiparam-se às autoridades, para os efeitos desta Lei, os representantes ou órgãos de partidos políticos e os administradores de entidades autárquicas, bem como os dirigentes de pessoas jurídicas ou as pessoas naturais no exercício de atribuições do poder público, somente no que disser respeito a essas atribuições.

Assim, podemos perceber que, para a nossa legislação, o conceito de autoridade está diretamente ligado ao de poder de Estado, o qual retira sua legitimidade do momento fundacional. Destarte, assiste razão à Renato M. Perissinotto, que, citando Arendt e Ricouer, conclui que a autoridade é a institucionalização do poder (2004, p.121), pois ao diferenciar o poder (que emana do povo) do poder institucionalizado (autoridade), deixa muito claro que o primeiro, através da lei, limita e controla o segundo. Nesse sentido, através da Constituição e das leis os cidadãos recebem uma série de direitos, sendo necessário observar que a finalidade última de toda e qualquer norma é a realização de um interesse público. Portanto, a atuação do Estado, não importa por qual Poder se manifesta, deve visar atender ao bem comum, ao interesse da coletividade, se consubstanciado no dever de todo agente público atuar de acordo com a Lei.

Então, partindo de uma visão inspirada pelos estudos de Hannah Arendt, podemos dizer que a Lei, ao disciplinar a atuação de cada agente público, faz um elo de ligação com o momento fundacional (Poder), ou seja, a Lei institucionaliza o momento fugaz de agir em concerto da sociedade, possibilitando que o Estado e seu agente público atuem em prol de um objetivo comum a todos. 
Em verdade, ainda sob a luz dos estudos de Arendt, a qual identifica, em âmbito político, o papel da tradição de manter a autoridade intacta, percebe-se que Lei, ao se consubstanciar em um padrão e modelo aceito por todos, faz, no âmbito jurídico, as vezes da tradição, pois "remete aos antepassados que inicialmente presenciaram e criaram" a nossa Constituição Federal de 1988. Nesse diapasão, vejamos o caput do artigo $1^{\circ}$ da Lei $n^{\circ}$. 13.869/2019 (Lei de Abuso de Autoridade): “Art. $1^{\circ}$. Esta Lei define os crimes de abuso de autoridade, cometidos por agente público, servidor ou não, que, no exercício de suas funções ou a pretexto de exercê-las, abuse do poder que lhe tenha sido atribuído.”.

Ocorre que, ao comprarmos o referido dispositivo legal com antiga Lei $\mathrm{n}^{\circ}$. 4.898/1965 (antiga lei de abuso de autoridade), podemos identificar que esta utiliza a expressão "abuso de poder" da seguinte forma: "Art. $4^{\circ}$ Constitui também abuso de autoridade: a) ordenar ou executar medida privativa da liberdade individual, sem as formalidades legais ou com abuso de poder.”. Destarte, a nova Lei de Abuso de Autoridade, ao utilizar da expressão “...abuse DO poder que lhe tenha sido atribuído", bem como “...no exercício das suas funções...”, deixa muito claro que o 'poder', não reside no agente público, o que reforça os termos da própria Constituição, a qual declara “...todo poder emana do povo...", bem como nos remete a concepção Arendtiana de que o Poder está no agir em concerto, no momento fundacional. De fato, se o 'poder' fosse entendido como algo individual, residente em cada um, não poderíamos sequer falar em sociedade. Então, cria-se um poder institucionalizado (autoridade) que é limitado pela lei e atribuído ao agente público apenas ele manter a tradição do 'agir em concerto', por isso que quando a lei fala de 'abuso do poder', ela nos remete ao momento em que o agente público, feriu / desrespeitou o momento fundacional, quando deixou de agir em concerto e pós fim à tradição do agir em concerto inicial.

Interessante notar, ainda, que quando a Lei confere diversas prerrogativas para determinados agentes públicos, no intuito de que eles exerçam efetivamente suas funções em prol do interesse público, ela lhes garante meios de materializar a referida 'tradição' do agir em concerto inicial, ou seja, a Lei objetiva garantir que os agentes públicos, ocupantes de determinados cargos, busquem manter aquela tradição - em uma concepção arendtiana - de agir em concerto, e faz isso concedendo 'autoridade' a quem, pelos meios legais, comprove possuir conhecimento para tanto, ou foi escolhida pelo próprio Povo.

Portanto, a moderna concepção de autoridade, exercida por determinados agentes públicos, se aproxima do já exposto pensamento Weberiano acerca de dominação legalracional, ou seja, descansa sobre a crença na legalidade e tem pretensão de motivar 
racionalmente as condutas exigidas e o sistema como um todo, garantindo que ele não seja questionado. Assim, temos a presença de uma legitimação legal-racional, onde o Estado se sustenta para administrar a vida do cidadão, bem como controlar sua própria atuação.

Sendo assim, o agente público que legalmente tem autoridade, é aquele que tem a capacidade e o dever de, ao exercer sua função, refletir uma parcela do agir em concerto inicial (Poder), mantendo a tradição por meio da Lei, sob pena de ser responsabilizado por isso.

Por esta razão, nos Estados de Direito, toda e qualquer 'autoridade', eleita ou não, esta sujeita ao ordenamento jurídico, devendo ser individualmente punida quando desborda de suas prerrogativas para a satisfação de objetivos ilícitos ou de mero capricho pessoal. Trata-se do conhecido princípio da responsabilidade. Conforme esclarece o doutrinador português Paulo Otero, mas sem diferenciar as concepções de autoridade e poder:

O princípio da responsabilidade é, deste modo, um efeito do princípio democrático, traduzindo a ideia de que o exercício do Poder é sempre um serviço, um mandato, sujeito a prestação de contas, e não um privilégio outorgado em benefício de seu titular: responsabilizar quem exerce o Poder pelo modo como esse mesmo Poder é exercido revela também uma forma de interdependência limitativa do Poder. Não há Poder limitado sem mecanismos de responsabilização do Poder: no princípio da responsabilidade reside a primeira e, simultaneamente, a última garantia do Estado de Direito Democrático. (...) Porém, uma vez que o exercício do Poder não se esgota na atividade desenvolvida pelos titulares de cargos políticos, o princípio da responsabilidade tem um âmbito subjectivo de operatividade muito mais amplo: todos os intervenientes no exercício do Poder, exerçam ou não cargos políticos, são responsáveis pelas respectivas condutas. (OTERO, 2010, p. 33).

Então, ao fazermos uma leitura do artigo $1^{\circ}$ da Constituição Federal de 1988 e das disposições gerais da Lei $\mathrm{n}^{\circ}$. 13.869/2019, sob a luz das concepções de poder e autoridade analisadas no presente trabalho, percebe-se que a nova lei de abuso de autoridade deixa ainda mais evidente a diferença entre o 'poder' que emana do povo (poder) e o 'poder' institucionalizado (autoridade). É que este último pressupõe limites e responsabilidades para com o primeiro, sendo a criminalização de determinadas condutas praticadas por autoridades um grande exemplo disso, pois trata-se de lei penal utilizada como o último recurso para a manutenção do Estado Democrático de Direito.

\section{OS ELEMENTOS SUbJETIVOS DO TIPO E A MICROFÍ́SICA DO PODER NA SOCIEDADE BRASILEIRA}


Ao analisarmos o parágrafo $1^{\circ}$ do artigo $1^{\circ}$, presente nas disposições gerais da Lei $n^{\circ}$. 13.869/2019, é possível encontrarmos expressão que trata de elemento subjetivo de difícil comprovação e presente, em tese, tão somente na psique da autoridade, qual seja: “...por mero capricho ou satisfação pessoal". Então, para conseguir interpretar adequadamente a referida lei, bem como entender a relação de poder e autoridade tutelada por ela, deve-se compreender a razão da existência deste elemento subjetivo específico, sendo este o objetivo do presente tópico.

Dentre todas as concepções de poder e autoridade tratadas no presente trabalho, o estudo de Michael Foucault é o que mais ajuda a racionalizar o 'mero capricho' e a ‘satisfação pessoal' no contexto das relações de poder, uma vez que compreende o caráter microscópico de tais relações. Portanto, sob à luz da Microfísica do Poder, vejamos o parágrafo $1^{\circ}$ do artigo $1^{\circ}$ da Lei ${ }^{\circ} 13.869 / 2019$ (Nova Lei de Abuso de Autoridade):

Art. $1^{\circ}$. (...) $\S 1^{\circ}$ As condutas descritas nesta Lei constituem crime de abuso de autoridade quando praticadas pelo agente com a finalidade específica de prejudicar outrem ou beneficiar a si mesmo ou a terceiro, ou, ainda, por mero capricho ou satisfação pessoal.

Analisando o referido dispositivo legal, é possível perceber que ele esclarece a necessidade de dolo específico para todas as condutas típicas, inicialmente porque devem ser voltadas no intuito de prejudicar outrem ou beneficiar o agente político ou terceiro.

Contudo, a parte final do dispositivo em tela tem o condão de ampliar o dolo necessário para a configuração das condutas típicas do abuso de autoridade, uma vez que podem ser voltadas simplesmente ao mero capricho ou satisfação pessoal da autoridade, ou seja, para a configuração do crime, não há necessidade da demonstração de prejuízo ou benefício à vítima, autoridade ou terceiros, mas tão somente que a autoridade tenha agido, deixando de buscar o interesse público (de agir em concerto na concepção de Arendt), visando apenas o interesse próprio, portanto, ainda que não tenha qualquer benefício material com isso.

O fato de o legislador não exigir benefício material para a configuração da conduta típica, mas tão somente um "mero capricho", deixa muito clara a percepção e insatisfação da população brasileira com as relações de poder (Microfísica do Poder) em que o agente público utiliza da 'autoridade' para alcançar um 'poder' que não é seu, ou seja, corrompe a tradição constitucional, fazendo transparecer que o 'poder' emana dele e não do povo (que agiu em concerto no estar junto original). Sendo assim, a microfísica do poder de Michael Foucault nos ajuda a explicar a necessidade e alcance da expressão “...por mero capricho ou satisfação 
pessoal”, pois partindo do princípio de que o 'poder' também está presente nas pequenas relações humanas e que os detentores da 'autoridade' conferida pela lei são seres humanos com motivações e pensamentos próprios, então, é natural que lei busque controlar o pensamento individualista a partir de elementos presentes na psique da autoridade, devendo o direito trazer a racionalidade necessária para este controle.

No caso do Brasil não é incomum que a dinâmica das relações de poder (microfísica do poder) se desenvolve a partir do objetivo de um indivíduo (normalmente portador de 'autoridade') se diferenciar dos demais, em uma verdadeira falta de noção de república, entendida aqui não apenas como o sistema republicano em si, mas também no sentido de “coisa pública" (res publica), como um sentimento coletivo de zelar por aquilo que não fosse estritamente seu. Desde o período colonial a falta de uma meta comum, de um interesse geral ou projeto coletivo já foi denunciada por Frei Vicente do Salvador que no século XVII dissertou:

(...) os que cá nasceram, que uns e outros usam da terra, não como senhores, mas como usufrutuários, só para a desfrutarem, e a deixarem destruída.

Donde nasce também, que nenhum homem nesta terra é repúblico, nem zela, ou trata do bem comum, senão cada um do bem particular. Não notei eu isto tanto quanto o vi notar um bispo de Tucuman da Ordem de S. Domingos, que por algumas destas terras passou para a Corte, era grande canonista, homem de bom entendimento e prudência, e assim ia muito rico; notava as coisas, e via que mandava comprar um frangão, quatro ovos, e um peixe, para comer, e nada lhe traziam: porque não se achava na praça nem no açougue, e se mandava pedir as ditas coisas, e outras muitas a casas particulares lhas mandavam, então disse o bispo verdadeiramente que nesta terra andam as coisas trocadas, porque toda ela não é república, sendo-o cada casa; e assim é, que estando as casas dos ricos / ainda que seja a custa alheia, pois muitos devem quanto têm / providas de todo o necessário, porque tem escravos, pescadores, caçadores, que lhes trazem a carne e o peixe, pipas de vinho e de azeite, que compram por junto: nas vilas muitas vezes se não acha isto a venda. Pois o que é fontes, pontes, caminhos e outras coisas públicas é uma piedade, porque atendo-se uns aos outros nenhum as faz, ainda que bebam água suja, e se molhem ao passar dos rios, ou se orvalhem pelos caminhos, e tudo isto vem de não tratarem do que há cá de ficar, senão do que hão de levar para o reino. (SALVADOR, 1627, p. 04, grifo nosso).

Destarte, o Estado Português não preservava a vida do colono, que não preservava os interesses de Portugal ou da igreja, a própria mão de obra escrava (trazida a força e dominante) não era tratada como algo que devia ser preservado, ou seja, era cada um por si em uma microfísica do poder que está presente em toda a história de nosso país, até os dias de hoje, onde o 'poder' é utilizado sempre como prerrogativa no intuído de ser diferente dos demais cidadãos. Então, percebe-se que, no Brasil, a falta do sentimento de república nos traz 
a ideia de que ser cidadão, e, portanto, igual aos demais, é entendido como algo negativo, um insulto, ao passo que ser diferente é melhor. Ora, quando a revolução francesa chamou a todos de cidadãos ela nos trouxe justamente a ideia de igualdade, um de seus tripés (igualdade, liberdade e fraternidade), mas tal igualdade, no Brasil, parece ser entendida como algo pejorativo no momento em que a microfísica do poder de nossa sociedade se desenvolve no intuito de buscar a diferença e não a igualdade.

Até mesmo no atual contexto de pandemia, onde a lei exige de todos a prática de determinadas condutas em prol da saúde pública, é possível identificarmos aqueles que justificam sua desobediência à norma, que deveria ser seguida por todos os cidadãos, porque são diferentes. ${ }^{3}$

Ocorre que essa mesma microfísica do poder, observada desde o século XVII até os dias de hoje, também se desenvolve dentro do processo penal brasileiro, onde o agente público, em vez que cuidar da coisa pública (devido processo legal), utiliza da 'autoridade' concedida por lei para suprir um desejo próprio, o que muitas vezes entra em conflito com a norma que deve ser obedecida por todos, motivo pelo qual diversos dispositivos da Lei $\mathrm{n}^{\circ}$. 13.869/2013 criminalizam determinadas condutas voltadas ao desrespeito do Código de Processo Penal, ainda que 'por mero capricho ou satisfação pessoal', expressões que traduzem a preocupação do legislador com o que Michel Foucault denominou de microfísica do poder, ou seja, busca-se tutelar não apenas as relações de poder que são vistas nas grandes operações policiais ou julgamentos, mas também as pequenas relações observáveis no dia a dia do fórum.

Diante disso, sob a ótica da microfísica do poder, conclui-se que os elementos subjetivos 'por mero capricho' e 'satisfação pessoal', presentes na parte final do parágrafo $1^{\circ}$ do artigo $1^{\circ}$ da Lei $n^{\circ}$. 13.869/2019, se dedicam a combater, quase que de maneira pedagógica, a falta de pensamento republicano de agentes públicos dotados de um poder institucionalizado (autoridade), pois ao fazer a lei adentrar na psique do agente, o legislador demonstra o quão reprovável é a ausência de um pensamento republicano, bem como evidencia a importância de que o exemplo venha daqueles que têm o dever de manter a tradição constitucional ('autoridade' conferida pela lei). Nesse sentido, fica muito claro que o elemento subjetivo exigido pela Lei $\mathrm{n}^{\circ}$. 13.869/2019 não se configura apenas quando é identificável o prejuízo de outrem ou mesmo qualquer espécie de benefício a autoridade ou a

\footnotetext{
${ }^{3}$ Como exemplo vide algumas notícias publicadas no sítio g1.globo.com (LIMA, 2020) e (Fiscais...,2020).
} 
terceiro, mas também quando sua atuação é contrária às formalidades legais, já que o 'por mero capricho' e 'satisfação pessoal' significam a ausência de pensamento republicano da autoridade, um agir em contrariedade à satisfação do interesse público.

\section{CONCLUSÃO}

Partindo de uma hermenêutica jurídica, ao analisar cada uma das concepções de Poder e Autoridade dos filósofos supracitados, fica evidente que a Lei ${ }^{\circ}$. 13.869/2019 se dedica a controlar racionalmente o poder institucionalizado (autoridade), uma vez que ao utilizar de expressões como “...abuse do poder que lhe tenha sido atribuido." e “...mero capricho ou satisfação pessoal”, ressalta que o poder emana do povo e possibilita a aplicação da lei em diversos casos concretos. Nesse sentido, a necessidade do advento da Lei ${ }^{\circ}$. 13.869/2019 denuncia a falta de observância das normas constitucionais pelos tribunais (inclui-se as comarcas de primeiro grau), não apenas a partir de suas decisões, que na maioria das vezes se mostram incapazes de assegurar um direito constitucional não declarado em lei federal, mas também em virtude da ineficácia de seus órgãos correcionais.

Percebe-se que, até certo ponto, a criminalização de condutas praticadas em abuso de autoridade é oriunda dos mesmos fenômenos que incentivam a criação de outras leis criminais em nosso pais, a falta de políticas públicas adequadas e a ineficiência de procedimentos administrativos. Ou seja, em vez de atuar preventivamente, desenvolvendo políticas públicas voltadas a garantir, a todos, oportunidades de renda, saúde, educação etc. criminaliza-se condutas. Da mesma forma, em vez de investir em fiscalização, correição e procedimentos administrativos eficazes, criminaliza-se condutas.

Pelo menos, a criminalização de condutas praticadas em abuso de autoridade se consubstancia em reforço das normas constitucionais garantidoras de direitos fundamentais (p. ex. devido processo legal e presunção de inocência), bem como exige daqueles que já tem acesso à renda (fixa), educação, saúde etc. apenas a prestação de um serviço.

\section{REFERÊNCIAS BIBLIOGRÁFICAS}

ARENDT, Hannah. A condição humana. Trad.: Roberto Raposo. Posfácio de Celso Lafer. 10.ed - Rio de Janeiro: Forense Universitária, 2007. 1999.

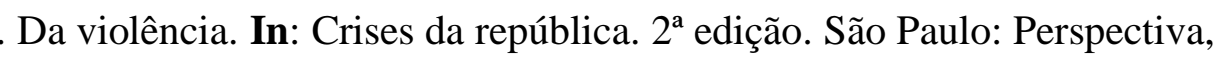

Perspectiva. 1979.

Entre o passado e o futuro. Trad.: M. W. Barbosa. São Paulo: 
ARISTÓTELES. A política (T. Guimarães, Trad.). São Paulo: Martin Claret, 2004.

BANDEIRA DE MELLO, Celso Antônio. Curso de direito administrativo. $32^{\mathrm{a}}$ edição, São Paulo: Editora Malheiros, 2015.

BÍBLIA, N. T. Provérbios. In: A Bíblia Sagrada: Contendo o Velho e o Novo Testamentos. Salt Lake: A Igreja de Jesus Cristo dos Santos dos Últimos Dias, 2015, p. 1738.

BRASIL. Constituição (1988). Constituição da República Federativa do Brasil de 1988.

BRASIL. Lei $N^{\mathbf{0}}$ 12.016, de 07 de agosto de 2009. Disciplina o mandado de segurança individual e coletivo e dá outras providências.

BRASIL. Lei $\mathbf{N}^{\mathbf{0}} \mathbf{1 3 . 8 6 9}$ de 05 de Setembro de 2019. Dispõe sobre os crimes de abuso de autoridade; altera a Lei $\mathrm{n}^{\circ} 7.960$, de 21 de dezembro de 1989, a Lei $\mathrm{n}^{\circ}$ 9.296, de 24 de julho de 1996, a Lei $\mathrm{n}^{\circ} 8.069$, de 13 de julho de 1990, e a Lei $\mathrm{n}^{\circ} 8.906$, de 4 de julho de 1994; e revoga a Lei $\mathrm{n}^{\circ}$ 4.898, de 9 de dezembro de 1965, e dispositivos do Decreto-Lei ${ }^{\circ}$ 2.848, de 7 de dezembro de 1940 (Código Penal).

FERREIRA, Aurélio Buarque de Holanda. Novo Aurélio século XXI: o dicionário da Língua Portuguesa. $3^{\text {a }}$ ed. revista e ampliada. Rio de Janeiro: Nova Fronteira, 1999.

Fiscais sofrem ataques ao reprimir aglomerações em bares do Rio; veja flagrantes. Fantástico, 2020. Disponível em: < https://g1.globo.com/fantastico/noticia/2020/07/05/fiscais-sofremataques-ao-reprimir-aglomeracoes-em-bares-do-rio-veja-flagrantes.ghtml>. Acesso em: 24/08/2020.

FOUCAULT, Michel. Microfísica do Poder. In: MACHADO. Roberto (Org. e trad.). Rio de Janeiro: Edições Graal, 1979.

SALVADOR, Frei Vicente do. História do Brasil. Bahia: Biblioteca Nacional, 1627 Disponívelem: $<$ http://www.dominiopublico.gov.br/pesquisa/PesquisaObraForm.do?select act ion=\&co_autor $=156>$. Acesso em 30/01/2020.

LIMA, Isabella. Desembargador humilha guarda após multa por não usar máscara em SP:

'Analfabeto'. G1 Santos, 2020. Disponível em: <https://g1.globo.com/sp/santosregiao/noticia/2020/07/19/desembargador-humilha-guarda-apos-multa-por-nao-usar-mascaraem-sp-analfabeto.ghtml>. Acesso em: 21/07/2020.

MEIRELLES, Hely Lopes. Direito administrativo brasileiro. $42^{\circ}$ edição, São Paulo: Editora Malheiros, 2016.

Mulher que discutiu com fiscal e disse que marido era melhor por ser 'engenheiro civil' é demitida. G1 Rio, 2020. Disponível em: <https://g1.globo.com/rj/rio-dejaneiro/noticia/2020/07/06/mulher-flagrada-humilhando-fiscal-em-reportagem-do-fantasticoe-demitida.ghtml> . Acesso em 26/08/2020.

OTERO, Paulo. Direito Constitucional Português. Coimbra: Almedina, $1^{\text {a }}$ edição, 2010. 
PERISSINOTTO, Renato M. Hannah Arendt, poder e a crítica da "tradição". In Revista Lua Nova, São Paulo, n. 61, 2004.

PLATÃO. A república ou da justiça (B. E. Bauru, Trad.). São Paulo: Edipro, Santo Agostinho, 2006.

TORRES, Maria Carmen Euler; CASTRO, Lucia Rabello de. Disponibilidade ao outro: construindo novas formas de autoridade entre adultos e crianças. In Psicologia da Educação. São Paulo, 38, $1^{\circ}$ sem. de 2014.

WEBER, Max. Economia e Sociedade: Fundamentos da Sociologia Compreensiva. Vol. 1. Trad.: Regis Barbosa e Karen Elsabe Barbosa. $3^{\text {a }}$ Ed. - Brasília: Editora Universidade de Brasília, 2000.

. Economia e Sociedade: Fundamentos da Sociologia Compreensiva. Vol. 2. Trad.: Regis Barbosa e Karen Elsabe Barbosa. Brasília: Editora Universidade de Brasília, 1999. 